\title{
Proměny postojů učitelů ke kurikulární reformě a jejímu zavádění 1
}

\author{
Karolína Pešková, Tomáš Janko, Tomáš Janík, \\ Michaela Spurná \\ Masarykova univerzita, Pedagogická fakulta / Filozofická fakulta
}

\begin{abstract}
Abstrakt: Cílem této studie bylo popsat proměny postojů učitelů Zš ke kurikulární reformě a jejímu zavádění. $K$ zachycení proměn postojů v průběhu času (deset let) jsme zkoumali postoje učitelů retrospektivně $v$ rámci těchto tři pozic: očekávání učitelů vưči kurikulární reformě před jejím zavedením, silné momenty, které učitelé prožili při zavádění kurikulární reformy do praxe, a postoje učitelů ke kurikulární reformě a jejímu zavádění dnes. V rámci kvalitativního šetření byly realizovány polostrukturované rozhovory s 18 učiteli vyučujícími na základních školách. Při analýze dat bylo využito tematické, axiální a selektivní kódování. Výzkum poukázal na značné individuální rozdíly $v$ postojových trajektoriích zahrnujících zmíněné tři pozice. Respondenti byli rozděleni do tří základních skupin dle současného převažujícího postoje: pozitivní - „fandíci““, neutrální - „balancujíci““ a negativní - „rozčarovani““. „Fandící“ učitele charakterizovala převaha vnímaných pozitiv reformy, ztotožnění se s ideou reformy a odeznění negativních pocitů. „Balancujíci““ se vyznačovali ambivalentními postoji, přičemž si byli vědomi jak pozitivních, tak negativních stránek proběhlé reformy. Skupina „rozčarovaných“ pak byla vůči reformě převážně negativně naladěná, a to vlivem různých selhání a nedostatků, které z jejich pohledu reforma přinesla.
\end{abstract}

Klíčová slova: proměny postojů, učitelé ZŠ, kurikulární reforma

\section{The Changes of Teachers' Attitudes Towards Curriculum Reform and Its Implementation}

Abstract: The aim of this study was to describe the changes of primary and lower secondary school teachers' attitudes towards curriculum reform and its implementation. In order to capture the attitudes changes retrospectively in the selected time span of ten years we looked at the attitudes from these positions: teachers' expectations of curriculum reform before its implementation, critical moments which teachers experienced during the implementation and teachers' attitudes towards the reform today. Qualitative investigation included semi-structured interview with 18 teachers teaching at primary and lower secondary schools. Data was analysed by means of thematic, axial, and selective coding. The research showed individual differences in attitude trajectories including the three positions. Respondents were divided into three basic groups according to their prevailing current attitude: positive - "supporting", neutral - "balancing", and negative - "disenchanted". The "supporting" teachers were characterised by prevailing positive perceptions of the reform, agreement with the reform ideas and negative feelings fading out. The "balancing" teachers had ambivalent attitudes and were aware of both positive and negative aspects of the reform. The group of "disenchanted" teachers was primarily negatively oriented because of various failures and shortcomings which the reform brought from their point of view.

Keywords: changes of attitudes, lower secondary school teachers, curriculum reform

1 Studie vznikla za podpory projektu GA ČR Mezi akceptací a resistencí: Vnímání kurikulárních změn učiteli $v$ období deseti let od implementace reformy (GA15-05122S). 
70 Reformy kurikula mají napomáhat vyšší kvalitě vzdělávání, souvislosti jejich zavádění mnohdy však učitele spíše polarizují. Rozrůzněnost, ale i dynamika postojů k reformám, které se u učitelů utvářejí v průběhu jejich zavádění, může být značná. Postoje učitelů k reformám kurikula mohou v průběhu času vykazovat specifické trajektorie, jež bývají poměrně individuální. Jednotliví učitelé totiž nějakým způsobem zaváděnou reformu vnímají, prožívají a hodnotí, v důsledku čehož se někde na škále mezi akceptací a resistencí vymezuje nejen jejich vztah k reformě, ale také akční prostor, $v$ němž jsou ochotni se $v$ reformě více angažovat.

Cílem této studie je popsat postoje učitelů ZŠ ke kurikulární reformě a jejímu zavádění z hlediska osobního dopadu a zároveň nahlédnout na proměny postojů učitelů $v$ průběhu času. Svým zaměřením náleží do série textů, které pišeme s cílem osvětlit různorodé aspekty reformy kurikula v ČR v posledních letech (viz např. Janík et al., 2018; Janík, 2013; Janík et al., 2010; Píšová et al., 2011).

\section{Z výzkumů postojů ke kurikulární reformě}

V kvalitativních studiích zabývajících se kurikulární reformou je výzkumná pozornost obvykle zaměřena na osobnostní, či profesní charakteristiky učitelů. Postoje učitelů k reformě jsou zde pak pojaty jako relativně stálé struktury, pohybující se na kontinuu mezi akceptací a resistencí. Naproti tomu výzkumné studie, které by se postoji učitelů ke kurikulární reformě zabývaly dynamicky, tj. z hlediska vývoje $\checkmark$ čase (trajektoriemi postojů) jsou poměrně ojedinělé.

Celkovou nespokojenost s reformou ze strany učitelů potvrzují výzkumy realizované u nás a $v$ zahraničí, které naznačují, že reforma nepřinesla změny, které učitelé očekávali. Např. výzkum realizovaný na Slovensku kolektivem Porubského et al. (2016) poukázal na ambivalenci postojů z hlediska očekávání a současných postojů k reformě - učitelé si reformu přáli, ale její aktuální podobu nepřijali.

Rozsáhlý kvalitativní výzkum mapující postoje českých učitelů ke kurikulární reformě realizoval Janík et al. (2010). Výsledky ukázaly, že učitelé a koordinátoři školních vzdělávacích programů se k novému kurikulu staví rozporuplně. Reformu celkově vítají jako př́ležitost pro uskutečnění změn vztahujících se např. k profilaci školy, výběru vzdělávacích obsahů, či inovativním metodám výuky. Naproti tomu hlavní ideje a cíle reformy jsou učiteli chápány nejednoznačně. Nízká informovanost o smyslu a důvodech probíhajících změn kurikula, nízká míra finanční a metodické podpory při zavádění těchto změn jsou další z faktorů ovlivňující postoje učitelů k reformě, jež jsou zmiňovány i v dalších (zahraničních) kvalitativně orientovaných výzkumech (např. Hardman \& A-Rahman, 2014; Karakhanyan, van Veen, \& Bergen, 2011).

Lee (2000) konstatuje, že hongkongští učitelé hodnotí změny kurikula především z hlediska očekávaného př́nosu pro výuku. Významné však podle autora mohou být i další faktory - vedle organizační a časové náročnosti i realizovatelnost principů reformy $\vee$ praxi. Dle Floresové (2005) je pro některé portugalské učitele $\vee$ jejím 
výzkumném souboru rozhodující dostatečná volnost (flexibilita) při plánování a realizaci změn kurikula. Naopak pocit'ují-li učitelé nedostatek informací či materiální a metodické podpory, mohou při implementaci kurikulárních změn inklinovat $\mathrm{k}$ zaběhnutým (formálním) postupưm, a to i když se změnami v obecné rovině souhlasí. Sdílení zodpovědnosti a jasné vedení při implementaci byly jako rozhodující faktory kurikulárních změn identifikovány ve studii Jorgensena, Walshe a Niescheho (2009). Autoři prostřednictvím etnografického šetření s australskými učiteli zjistili, že jsou-li uvedené aspekty naplněny, může docházet $\mathrm{k}$ hlubšímu porozumění podstatě kurikulárních změn a následnému přijetí souvisejících rolí. V neposlední řadě hraje při utváření postojů učitelů a jejich proměně roli intenzita proživání dané kurikulární změny, i když se jedná dle nizozemských výzkumníků o projevy velice individuální (van Veen \& Sleegers, 2006).

Lazarová (2005) považuje za klíčový faktor, který motivuje učitele k inovacím a spolupráci na změnách, osobnostní rozvoj. Jedná se zejména o schopnost sebepoznání a sebereflexe ve vztahu k výkonu povolání i dalšímu vzdělávání. Naproti tomu negativně může postoje učitelů ke kurikulární reformě ovlivňovat i jejich pocit, že byli při reflexi praktických aspektů své výuky vzhledem k filosofii kurikulární reformy ponecháni osamoceně. Podle Dvořáka, Starého a Urbánka (2015) může být důležitým aspektem podmiňujícím implementaci kurikulárních změn (ne)soulad mezi vzdělávací vizí školy a oficiálním diskurzem kurikulární reformy. Odlišnosti mezi těmito rovinami mohou podle autorů vést až $\mathrm{k}$ tomu, že i přes potenciál participujících škol ke změně bude reforma vnímána jako celek skepticky a její implementace bude probíhat jen formálně. Realizace kurikulárních změn však může být silně podmíněna i specifickou kulturou konkrétní školy. $V$ určitých případech na některých školách může docházet $\mathrm{k}$ verbálnímu odmítání reformy na jedné straně, ale současně $\mathrm{k}$ realizaci některých reformou zamýšlených změn na straně druhé (srov. Moree, 2013).

Pokud pohlédneme na konkrétní typy učitelů z hlediska jejich postojů ke změnám kurikula, můžeme zmínit napřílad výzkum Vähäsantanenové a Eteläpeltové (2011), které na základě hloubkových rozhovorů s finskými učiteli rozlišují mezi těmito učiteli: (1) učitelé, kteří implementaci reformy zvládají a cítí se reformou posíleni, (2) učitelé, kteří s reformou spojují pozitivní očekávání, (3) učitelé, kteří jsou k reformě kritičtí, ale snaží se přizpưsobit, a (4) učitelé, kteří se s implementací reformy potýkají. Rozhodující aspekt ovlivňující postoje učitelů představuje dle autorek to, do jaké míry změny korespondují s profesní identitou. Podobně Rekkor, Ümarik a Loogmanová (2013) rozlišují mezi učiteli, jež reformu aktivně přijímají, tj. nepocit'ují konflikt mezi principy reformy a vlastním pojetím výuky (entusiastičtí inovátoři, konstruktivně-kritičtí inovátoři, př́jemci norem), a naopak učiteli s negativně orientovanými postoji, kteři nové kurikulum chápou jako zvýšenou administrativní zátěž, jež nepřináší reálné zlepšení v každodenní výukové praxi (ignoranti norem, přesvědčení odpưrci). 


\section{Teoretická východiska ke zkoumání proměn postojů $\mathrm{k}$ reformě kurikula}

Postoje lze obecně definovat jako hodnotící vztah k určitému objektu (Ajzen, 2001) nebo lépe jako psychologickou tendenci, která je vyjádřena hodnocením objektu jistým stupněm libosti, či nelibosti (Eagly \& Chaiken, 1993)². Podstatnou součástí postojů je hodnocení atributů a asociací přisuzovaných danému objektu (Ajzen, 2001), vycházejících z kognitivních a afektivních reakcí na daný objekt (Crano \& Prislin, 2006). Dominantní postavení v postojích má dle některých autorů afektivní emoční složka (Ajzen, 2001; Ajzen \& Fishbein, 2005). I přes to, že jsou všechny složky (v klasické teorii postojů se jedná o kognitivní, afektivní, konativní složku) nezbytné pro komplexnost postojư ${ }^{3}$, emoce mohou ovlivňovat ostatní složky a určovat tak celkové směřování postojů.

Postoj člověka je možné zjistit na základě jeho vyjádření na kontinuu bipolární hodnotící dimenze (Výrost, 2008). Postojovému objektu jsou přisuzovány určité vlastnosti, přičemž vznikají přesvědčení o daném objektu. Postoj osoby je pak funkcí těchto vlastností. Podle Fischbejna a Ajzena (1975; cit. dle Výrosta 2008, s. 133) může mít člověk mnoho přesvědčení o určitém objektu, ale jen omezený počet slouží jako determinanta postoje mající klíčový, integrující charakter. Pokud nejsou postoje kognitizované (odůvodněné), jsou založeny jen na emoční úrovni a mají spíše implicitní charakter.

I když jsou postoje z části vrozené, většinu lze získat v průběhu života prostřednictvím vlastní nebo zprostředkované osobní zkušenosti s objekty (Brendl \& Higgins, 1996; cit. dle Výrost 2008, s. 127). Celkové hodnocení objektu se může proměňovat v závislosti na různém kontextu a může se s odstupem času oslabit nebo zesílit (viz Fabrigar, MacDonald, \& Wegener, 2005). Přitom právě osobní zkušenosti mají dle řady výzkumů na tvorbu a změnu postojů největší vliv (viz např. Petty \& Cacioppo, 1986). Prostřednictvím př́mé zkušenosti dochází ke kognitivnímu vytváření vztahu k objektu a zexplicitnění postojů. Bez prožité zkušenosti je postoj většinou neodůvodněný a primárně emočně založený.

Za výchozí moment pro zachycení proměny postojů lze považovat první očekávání vưči danému objektu nebo jevu. Na očekávání lze nahlížet jako na jednu ze stěžejních determinant postojů, resp. jako na „spouštěč“ stavu (ne)spokojenosti s určitou

2 V odborné literatuře je možné se setkat $\mathrm{s}$ odlišným pojetím vztahu $\mathrm{k}$ objektu v rámci teorie sociálních reprezentací. Dle této teorie na rozdíl od teorie postojů objekt nepoznáváme prímo, ale zprostředkovaně skrze kulturu, jazyk a konvence společnosti, ve které žijeme. Tím nezaujímáme postoj k samotnému objektu, nýbrž k jeho sociální reprezentaci (Moscovici, 1984, cit. dle Plichtová, 1998, s. 505). Pojem sociální reprezentace tak označuje soubor názorů a přesvědčení, které se utvářejí ve společenských skupinách (s. 504), chápeme jej v porovnání s pojmem postoj na vyšší úrovni abstrakce. $V$ této studii vycházíme z pưvodní struktury teoretického modelu CBAM (Concerns-Based Adoption Model) zaměřeného na vnímání inovace, $v$ němž postoje $\mathrm{k}$ inovaci představují jednu ze složek modelu (viz Pešková, Spurná, \& Knecht, 2017).

3 V souvislosti s vnitřní strukturou postojů neexistuje shoda mezi autory $v$ tom, zda jsou postoje spíše jednodimenzionálního charakteru (s dominancí emocí), či mají vícedimenzionální strukturu (viz Fazio \& Olson, 2003; Chaiken \& Stangor, 1987). 
situací nebo určitým objektem (Ajzen, 2001; Spreng, MacKenzie, \& Olshavsky, 1996). Člověk si vytváří očekávání k objektu nebo situaci a následně zažívá realitu. Mezi očekáváními a realitou mohou pak vznikat diskrepance, jež vedou ke spokojenosti/ nespokojenosti s daným stavem a které se následně promítají do výsledného postoje.

Postoje je možné dále diagnostikovat na základě informací, které se z hlediska daného jedince jeví jako stěžejní: emocionální reakce vyvolané daným objektem postoje, předchozí jednání související s objektem, přímá zkušenost s objektem apod. (Fazio, 1995). Tyto reflektované zkušenosti a emocionální reakce na objekty v této studii označujeme jako silné momenty učitelů. Jedná se o vnější zdroje, jež mohou postoje ovlivnit, resp. mají potenciál postoje změnit ${ }^{4}$ - např. charakteristika hodnoceného objektu (jeho původ, informace o objektu) či situační zkušenost (situační učení) jako zdroj přesvědčování (persvaze) sebe sama nebo okolím (Fishbein \& Ajzen, 1975; dále viz Kruglanski \& Stroebe, 2005). Emocionálně laděná persvaze může navodit změnu postoje prostřednictvím vyvolané intenzivní emocionální reakce, dle některých studií snadněji prostřednictvím emocionálních reakcí negativních (viz Výrost, 2008). Přitom hraje roli i to, zda je postoj již racionalizovaný - založený na vlastních přesvědčeních vyplývajících z vlastní zkušenosti s objektem, či je pouze obecný, tj. „nepodložený“ vlastními prožitky.

V našem výzkumném šetření vycházíme z předpokladu, že postoje učitelů ke kurikulární reformě jsou vlivem jejich zkušeností dynamické (van Veen \& Sleegers, 2009; Vähäsantanen \& Eteläpelt, 2011) a přistupujeme k jejich zkoumání z několika zmíněných pozic - ve vztahu k očekáváním vưči reformě (před jejím zaváděním), k silným momentům, které učitelé prožili během zavádění (seznamování se s reformou), a z hlediska současného stavu (s časovým odstupem od zavádění). Podobně jako např. Waugh a Punch (1987) nahližíme na očekávání vưči reformě a na zkušenosti a prožitky během zavádění reformy jako na stěžejní determinanty, které mohou $\mathrm{k}$ proměně postojů $\mathrm{k}$ reformě přispět. Zároveň se nám jeví jejich sledování vhodné z časového hlediska, jelikož představují klíčové fáze reformy. Tyto tři zmiňované pozice nám umožňují charakterizovat „postojové trajektorie“ učitelů, které jsou v centru pozornosti této studie.

\section{Cíl a metodický postup výzkumu}

Dosavadní výzkum postojů ke kurikulární reformě v ČR poukázal na řadu problémů, které s sebou v očích učitelů kurikulární reforma přinesla (viz např. Janík et al., 2010, 2011; Dvořák, Starý, \& Urbánek, 2015). Doposud však do hloubky neodkryl, jak na reformu učitelé nahližejí retrospektivně s časovým odstupem, zda a jak se

$4 \quad \mathrm{~V}$ anglicky psané odborné literatuře se můžeme setkat s pojmem critical incidents (kritické momenty), které jsou chápany jako významné události nebo situace sloužící jako „katalyzátory“ změny $v$ životě osoby nebo nějakého sociálního fenoménu - v kontextu profesního života učitele viz např. Angelides, 2001; Tripp, 1994). Dle Moreeové (2013) jsou dưležité pro zkoumání zásadních zvratů v dění na konkrétní škole (viz také Goodson \& Anstead, 2012). 
74 jejich postoje $\mathrm{k}$ reformě $v$ průběhu času změnily a co $\mathrm{k}$ tomu přispělo. Prvotním záměrem této studie proto bylo nabídnout pohled na postoje učitelů z hlediska osobního dopadu - v průběhu času. Obecným cílem našeho výzkumu bylo popsat proměny postojů učitelů ZŠ ke kurikulární reformě a jejímu zavádění 5 . Objekt postojů, kurikulární reformu, jsme vymezili jako změnu ve školství spočívající v závazném zavedení nových kurikulárních dokumentů (RVP a ŠVP) a proces jejich aplikace učiteli v praxi (z časového hlediska ji sledujeme od roku 2007 až po současnost). K zachycení proměnlivosti postojů učitelů $v$ časovém rozmezí před zavedením reformy po současnost (přibližně deset let) jsme formulovali ve vztahu k výše uvedeným teoretickým východiskům tyto výzkumné otázky:

Jaká očekávání měli učitelé vưči kurikulární reformě před jejím zavedením?

Jaké silné momenty prožili při zavádění kurikulární reformy do praxe?

Jaké jsou postoje učitelů ke kurikulární reformě a jejímu zavádění dnes?

K zodpovězení výzkumných otázek bylo realizováno kvalitativní šetření využívající polostrukturovaného rozhovoru jako techniky sběru dat. Jednalo se o retrospektivní př́stup, tedy respondenti byli dotazováni pouze $v$ současnosti (s desetiletým časovým odstupem od zavedení reformy). Tvorba tazatelského schématu navazovala na výsledky předchozího dotazníkového šetření, které bylo zaměřeno na plošné zjišt'ování postojů učitelů k reformě ve vztahu k dalším proměnným (viz např. Pešková, Spurná, \& Knecht, 2017). Cílem kvalitativního šetření tak bylo mj. prohloubit a kontextualizovat výsledky kvantitativního šetření. Tazatelské schéma obsahovalo celkem 17 otázek ( $\mathrm{z}$ toho 5 otázek zaměřených na demografické údaje o učiteli, jeho subjektivní vnímání sebe sama jako učitele, jeho pojetí výuky). Pokrývalo témata jako učitelova očekávání vůči reformě, jeho role při zavádění reformy na škole, jeho přesvědčení o reformě, jeho zkušenosti a pocity s ní spojené, způsob práce s kurikulárními dokumenty, vnímání postojů k reformě ze strany vedení a kolegů. Otázky pro učitele byly na různé úrovni obecnosti. Byly formulovány jak explicitně (např. Jaká byla vaše očekávání $v$ souvislosti s reformou?), tak směřovaly k odkrytí implicitních struktur (např. $S$ čím vším jste se na vaši škole setkali při zavádění reformy?) ve vztahu ke sledovaným výzkumným otázkám. Tento způsob kombinování otázek přispěl k přijatelnému saturování dat.

$\mathrm{K}$ realizaci rozhovoru byli osloveni učitelé, kteří se podíleli na předchozím dotazníkovém šetření ${ }^{\text {. }}$ Výsledný výzkumný vzorek tvořilo 18 učitelů působících na základních školách $v$ různých regionech České republiky, z toho pět zastávalo $v$ době realizace výzkumu funkci ředitele. Podrobnější údaje o učitelích nabízí Tabulka 1.

5 V této studii se zabýváme pouze postoji učitelů ke kurikulární reformě. V rámci řešeného projektu vznikla taktéž studie (Spurná \& Knecht, 2018), která sleduje způsoby využívání kurikulárních dokumentů učiteli a nabízí další pohled na proběhlou kurikulární reformu z hlediska jejího praktického dopadu.

6 Výběr byl uskutečněn prostřednictvím tzv. koordinátorů dotazníkového šetření, kteři v předchozí fázi distribuovali dotazník na své vlastní škole a nyní oslovili znovu učitele s nabídkou realizace rozhovoru. 
Tabulka 1 Přehled kontextuálních údajů o výzkumném vzorku učitelů

\begin{tabular}{|c|c|c|c|c|c|}
\hline ID & Jméno & Pozice na škole & Délka praxe & Vyučované předměty & Kraj \\
\hline 1 & Patricie & učitelka & 16 let & učitelství pro 1. stupeň & Ústecký \\
\hline 2 & Jiřina & učitelka & 21 let & učitelství pro 1. stupeň & Ústecký \\
\hline 3 & Klára & učitelka & 15 let & učitelství pro 1. stupeň & Ústecký \\
\hline 4 & Zuzana & učitelka & 20 let & učitelství pro 1. stupeň & Ústecký \\
\hline 5 & Kamil & ředitel & 12 let & $\begin{array}{l}\text { český jazyk, dějepis, } \\
\text { občanská výchova }\end{array}$ & Liberecký \\
\hline 6 & Anna & učitelka & 5 let & $\begin{array}{l}\text { dějepis, německý jazyk, } \\
\text { anglický jazyk }\end{array}$ & Jihomoravský \\
\hline 7 & Pavla & učitelka & 3 roky & $\begin{array}{l}\text { občanská výchova, } \\
\text { dějepis }\end{array}$ & Jihomoravský \\
\hline 8 & Josef & ředitel & 20 let & český jazyk, dějepis & Jihočeský \\
\hline 9 & Julie & ředitelka & 32 let & matematika & Moravskoslezský \\
\hline 10 & Jarmila & ředitelka & 32 let & učitelství pro 1. stupeň & Ústecký \\
\hline 11 & Vendula & učitelka & 18 let & $\begin{array}{l}\text { občanská výchova, } \\
\text { tělesná výchova, zeměpis }\end{array}$ & Vysočina \\
\hline 12 & Jindřich & učitel & 24 let & učitelství pro 1. stupeň & Zlínský \\
\hline 13 & Anežka & učitelka & 29 let & $\begin{array}{l}\text { matematika, fyzika, } \\
\text { pracovní činnosti }\end{array}$ & Jihomoravský \\
\hline 14 & Svatopluk & učitel & 39 let & učitelství pro 1. stupeň & Zlínský \\
\hline 15 & Ida & ředitelka & 30 let & $\begin{array}{l}\text { př́rodopis, občanská } \\
\text { výchova }\end{array}$ & Jihomoravský \\
\hline 16 & Hana & učitelka & 20 let & učitelství pro 1. stupeň & Jihočeský \\
\hline 17 & Regína & učitelka & 20 let & $\begin{array}{l}\text { anglický jazyk, výtvarná } \\
\text { výchova }\end{array}$ & Jihočeský \\
\hline 18 & Jan & zástupce ředitele & 5 let & $\begin{array}{l}\text { dějepis, český jazyk, } \\
\text { anglický jazyk }\end{array}$ & Jihomoravský \\
\hline
\end{tabular}

Pro ujasnění tématu rozhovoru byl učitelům před zahájením rozhovoru vysvětlen pojem kurikulární reforma tak, jak je chápán pro účely našeho výzkumu, pro odlišení od jeho dalších možných interpretací (zdůrazněno bylo zaměření rozhovoru na zavádění RVP a ŠVP). Rozhovory s učiteli trvaly 45 až 90 minut (v průměru 70 minut). Byly realizovány osobně (11) nebo prostřednictvím programu Skype (6), nahrány na diktafon a poté doslovně transkribovány a anonymizovány (jména respondentů byla nahrazena pseudonymy). Analýza dat proběhla v programu MAXQDA 11. Nejdř́ve byla data analyzována po jednotlivých př́padech (vertikálně) prostřednictvím tematického kódování (dle předem stanovených 15 kategorií vč. podkategorií vycházejících z výzkumných otázek), přičemž byla ověřena reliabilita kódování, tj. shoda na úrovni kódovatelů. 
Míra reliability byla v souladu s doporučeními McHughové (2012) vypočítána jako přímá procentuální shoda mezi kódovateli. Šlo tedy o to stanovit, u kolika výroků se kódovatelé vzájemně shodnou - ohodnotí tvrzení respondentů prostřednictvím shodného kódu (srov. Graham, Milanowski, \& Miller, 2012; Watkins \& Pacheco, 2000). Na kódování dat se podílelo pět kódovatelů, kteří byli pro zajištění triangulace výzkumníků rozděleni do různých dvojic (celkem bylo vytvořeno pět dvojic, kódovatel tedy mohl výsledky kódování diskutovat s více výzkumníky). Shoda mezi kódovateli byla ověřena na dvou úrovních. Nejdříve byla vypočítána přímá shoda na základě porovnání kódů přidělených kódovateli jednotlivým nakódovaným segmentům. Zde se míra shody pohybovala $v$ rozmezí 50-60\%7. Poté následovala diskuse výsledků kódování, jejímž cílem bylo dosáhnout přijatelného konsensu výběru kódu mezi kódovateli. V této fázi se následně míra shody pohybovala nad hranicí $90 \%$, pouze v jednom prípadě dosáhla hodnoty $62 \%$, proto byly kódy dále diskutovány s ostatními kódovateli8 (dále viz Gläser-Zikuda, 2008).

Při analýze dat bylo využíváno kombinace vybraných postupů zakotvené teorie (tematické, axiální a selektivní kódování) ${ }^{9}$. V rámci tematického kódování vzniklo několik nových relevantních (pod)kategorií, na kterých se shodli všichni kódovatelé. Následně proběhla další analýza kódů a interpretace jedním kódovatelem napřič všemi případy - horizontálně (viz Miles \& Huberman, 1994) zaměřená na témata očekávání, silné momenty a postoje k reformě/kurikulárním dokumentům a jejich zavádění (selektivní a axiální kódování). V rámci kategorií vztahujících se $\mathrm{k}$ těmto tématům (kategorie nazvané očekávání, silný moment a smysluplnost - bilance včetně podkategorií RVP a ŠVP, které byly zaměřené na hodnocení těchto dokumentů) byly vytvořeny induktivně další kódy a podkategorie. Jednotlivé případy byly porovnávány mezi sebou, čímž se začaly odkrývat postojové trajektorie učitelů charakterizující jejich hodnotící vztah k reformě (pozitivní, neutrální, negativní) v časové posloupnosti očekávání vưči reformě - silný moment během zavádění reformy - současný postoj k reformě. Kódy vztahující se k ostatním tématům byly zohledněny pro kontextualizaci a dokreslení sledovaných trajektorií učitelů. Vzhledem k individuálnosti sledovaných trajektorií jsme učitele a jejich trajektorie rozdělili do tř́ zastřešujících skupin dle jejich převažujícího současného postoje - rozlišili jsme učitele s pozitivními, neutrálními a negativními postoji. Dle těchto skupin jsou výsledky prezentovány v následující kapitole.

7 Při bližším pohledu na případy (výroky), které byly hodnoceny jako neshoda, se ukázalo, že u kódovatelů nešlo o diametrálně odlišné posouzení. Obvykle se jednalo o nakódování výroku jiným kódem, který ale spadal do stejné skupiny/tř́idy kódů. Např́klad jeden kódovatel k nakódování výroku zvolil obecnější (hierarchicky nadřazený) kód, zatímco druhý kódovatel výrok nakódoval pomocí podrobnějšíno kódu.

8 Podle Gläser-Zikudy (2008, s. 79) lze za uspokojivou míru shody mezi kódovateli u dat získaných prostřednictvím deduktivně odvozených hodnotících kategorií považovat hodnotu 0,89 . Podobně Brückmannová et al. (2007) uvádí, že hodnota př́mé shody by měla dosáhnout alespoň 88-98\%. Dle Stemlera (2004) však lze za uspokojivou míru přímé procentuální shody považovat rozmezí 75-90\%.

9 Vzhledem k dalším charakteristikám zvoleného metodologického postupu (struktura rozhovoru, chybějící otevřené kódování atd.) však nelze hovořit o zakotvené teorii v pravém slova smyslu. 


\section{Výsledky výzkumu}

Současné (výsledné) postoje respondentů ke kurikulární reformě po deseti letech od jejího zavedení dělíme $v$ tomto textu $s$ jistým zjednodušením ${ }^{10}$ na pozitivní („fandíci““ učitelé), neutrální („balancujíci““ učitelé) a negativní („rozčarovani““ učitelé). $\checkmark$ př́padě pozitivních a negativních postojů se jedná o postoje vyhraněné, které dle prevažujících charakteristik směřují k pozitivnímu nebo negativnímu pólu. Rozdělení respondentů vychází z obsahu jejich převažujících výroků. Vzhledem $\mathrm{k}$ omezenému rozsahu studie však neuvádíme výroky všech respondentů, ale pouze ty, které jsou pro dané skupiny respondentů typické nebo zajímavé.

$\checkmark$ rámci prezentovaných skupin popisujeme vedle typických charakteristik této skupiny také trajektorie proměn postojů daných respondentů. Tyto trajektorie zahrnují: očekávání vůči reformě, silné momenty při zavádění reformy a současné postoje $\mathrm{k}$ reformě.

\subsection{Pozitivní postoje - fandící učitelé}

Z celkem 18 respondentů jsme rozlišili sedm s převažujícími pozitivními postoji k reformě. Jedná se o respondenty, kteří na reformě shledávají v současné době převážně pozitiva, souhlasí s ideou reformy a respektují ji. Jako jeden z hlavních prínosů reformy se respondentům jeví autonomie učitele při výuce a tvorbě kurikula. Např. učitelka Ida dává autonomii učitele do souvislosti s možností individualizované práce s žáky a osvobozením se od pevně stanovených osnov ve srovnání s předchozími kurikulárními dokumenty:

A myslím si, že... tomu učiteli to dává mnohem víc příležitostí, třeba i svobodněji pracovat... $s$ těmi dětmi, nebo $k$ těm dětem přistupovat... individuálně. Takže jako $z$ mého pohledu... to byla změna..., která může učitelům, pokud to vnímají stejně, přinést nějaký větši pocit svobody a možnost, prostě řekněme, vést tu výuku trošku volněji, že to sevření není až tak jakoby pevné, jak třeba se vnímalo do té doby. (učitelka Ida)

Téma autonomie se jeví jako společný jmenovatel pro respondenty s touto postojovou trajektorii: pozitivní očekávání - negativní silný moment - současný pozitivní postoj. Tyto respondenty (Zuzanu, Kamila a Idu), kteří shledávali pozitiva reformy ve větši autonomii učitele, spojují velká (pozitivní) očekávání před zavedením reformy. Očekávali změny, které pozitivně ovlivní jejich práci - např. možnost sebevzdělávání, prostor pro tvorbu ŠVP dle vlastních potřeb a v souladu s vizí školy či přizpůsobení ŠVP realitě, jak ilustruje výrok učitele Kamila:

Ale ta očekávání byla taková... ano, máme tady prostor pro to, abychom... našemu typu školy, našemu typu žáků, který víme, že s nima pracujeme, připravili takový vzdělávací

10 Jsme si vědomi skutečnosti, že postoje nelze jednoduše a černobíle kategorizovat, jelikož jsou komplexní a multidimenzionální povahy (viz např. Eagly \& Chaiken, 1993; Fabrigar, MacDonald, \& Wegener, 2005). Vycházíme z předpokladu, že výsledné postoje jsou sumativním hodnocením objektu zahrnujícím hodnocení jednotlivých atributů tohoto objektu (Eagly \& Chaiken, 1993). 
program, který je dle našeho nejlepšího svědomí a vědomí a podle těch zásad, jakými chceme s těmi dětmi pracovat a jak je chceme vzdělávat. (učitel Kamil)

Tato pozitivní očekávání všech tři učitelů však nebyla naplněna. Došlo k negativnímu silnému momentu, kdy na základě negativních zkušeností učitelé pocítili ve vztahu k reformě bezradnost, zklamání a rezervovanost. Bezradnost učitelky Zuzany např. spočivala $v$ nedostatku potřebných informací při zavádění nového kurikula:

Já jsem z toho neměla vůbec dobrý pocit, já jsem fakt nevěděla, co dělat, jak to uchopit, jo? (učitelka Zuzana)

Podobně jako u ostatních respondentů se současnými pozitivními postoji, došlo také např. v prípadě Zuzany po čase $\mathrm{k}$ rutinizaci práce s kurikulem a ke zmírnění počátečních negativních pocitů (bezradnosti) při zavádění reformy:

Potom, když už se to udělalo, utvořili jsme ty plány, tak se člověk zklidnil a vlastně mám to po ruce a jedu. Učím, už to nevidím. Ted' už to pro mě problém není. (učitelka Zuzana)

Podobnou trajektorii jako u Kamila, Idy a Zuzany můžeme pozorovat i u Anny: žádná očekávání - negativní silný moment - současný pozitivní postoj. V jejích výrocích nebyla sice reflektována žádná očekávání v souvislosti s reformou, avšak zažila počáteční bezradnost při tvorbě kurikula. Po čase také dospěla ke zklidnění, což lze vysvětlit nabytými zkušenostmi a dovednostmi a získanou jistotou při práci s kurikulárními dokumenty:

Tak ted' to vnímám tak, že tím, že už vím, co to obnáší... Tím, že jsem si to zkusila a prošla, tak už vím, že tam najdu spoustu odpovědí. Takže... ted' už jsem v klidu a jsem klidnější, že už s tím prostě umím pracovat. (učitelka Anna)

Jindřich oproti Anně byl již v počátku vưči reformě negativní, v jeho postojové trajektorii je tak možné zaznamenat ústřední zlom: negativní očekávání - negativní silný moment - současný pozitivní postoj. Tento zlom spočival v překonání negativních očekávání spojených se svazováním kompetencí učitele a překonání negativních pocitů z průběhu zavádění kurikula na škole (z důvodu nedostatku potřebných informací a pokynů k tvorbě ŠVP):

No, moje očekávání nebyla moc pozitivní. Opravdu, po pravdě řečeno, právě jsem se bál, že nás to bude nějak svazovat od té svobody, kterou jsem cítil, tím, že jsem měl prostě nějaké učivo a věděl jsem, že to učivo chci nějakým způsobem zvládnout, ale že ted' jsem věděl, tušil, že tam budu muset sledovat i další věci. Takže to očekávání bylo spíše trošičku negativní. (učitel Jindřich)

... A více méně jsem do toho byl nějak vhozen sám, aniž jsem měl ty teoretické poznatky. Takže jsem se tím musel jednak prokousat, jednak dělat konzultace s jinými kolegy, takže jsem byl trochu i naštvaný. Ale to není naštvání na tu reformu samotnou, ale spíše možná na způsob toho zadání, který jsme měli my uvnitř jako naší školy. (učitel Jindřich) 
Jindřich vnímal reformu po čase již jako samozřejmost, lze říci, že se s ní ztotožnil:

... Že to prostě vnímám jako nutnost. Naučil jsem se to... prostě vnímat jako nutnost,... na kterou nechci být naštvaný, bez níž to nejde. Prostě takhle to vnímám. Beru to jako realitu. (učitel Jindřich)

Nyní vnímá reformu celkově pozitivně (jako „věc, která je dobrá“), odevzdaně ji přijímá a vidí v ní (přes její některé negativní stránky) s odstupem času smysl.

Př́kladem respondenta s poměrně stabilním postojem (od počátků reformy) je učitelka Jarmila: pozitivní očekávání - žádný silný moment - současný pozitivní postoj. Již v počátku vnímala reformu jako prríležitost $\mathrm{k}$ vytvoření podmínek, jež budou vyhovovat škole a jejím žákům:

Takže jsem chtěla, aby každé dítě na naší škole mělo šanci, a v podstatě to jsme se do toho ŠVP nějakým způsobem snažili dát. A to byla i má očekávání, ... že chceme pracovat s dětmi, které mají nějaký handicap, ... a samožrejmě i s dětmi nadanými, prostě každému vytvořit takové podmínky, které si zaslouží. (učitelka Jarmila)

Očekávání Jarmily se naplnila, jelikož škole se podařilo profilovat žádoucím směrem. Zainteresovanost respondentky pro profilaci vlastní školy je stabilním jevem, jenž může mít vliv i na stabilitu postoje k reformě. Stabilita postoje v průběhu času poukazuje na jeho sílu, což může být dáno osobním zájmem o danou situaci, znalostí problému, častým přemýšlením o problému apod. (Ajzen, 2001; viz dále Krosnick \& Petty, 1995). Stabilitu postoje respondentky vystihuje i chybějící silný moment v její postojové trajektorii. V současnosti ŠVP vnímá jako „zákon“, který je na škole respektován:

A my vlastně z toho vycházíme samozřejmě, když se dělají tematické plány, že jo, takže to je pro nás opora, to je základní dokument, který prostě je a my se k němu vracíme, když jdeme na hospitace, jdeme do ŠVP, jdeme do tematických plánů, když je to všechno $v$ pořádku, abychom něco neopomněli, a jako tak to bereme jako opravdu náš zákon. Tečka. To nemá cenu proti tomu nějak brojit a myslím, že tady takhle si to vzali za své všichni. (učitelka Jarmila)

Poslední typ trajektorie představuje Jan, učitel s kratší učitelskou praxí (pět let), který zavádění reformy nezažil a neměl vưči ní tedy ani žádná očekávání (nezažil ani silný moment): žádná očekávání - žádný silný moment - současný pozitivní postoj. Ilustruje případ učitele, jenž nebyl ovlivněn vlastními zkušenostmi a seznámil se s reformou až po jejím zavedení. Jedná se také o poměrně silný pozitivní postoj, který nebyl ovlivněn vnějšími okolnostmi. Kurikulární dokumenty považuje za přirozenou součást učitelské praxe od jejího počátku:

Ale já v tom vidím hlavně tu praxi, kde máme rámcově vzdělávací programy, $z$ nich pak vznikají školní dokumenty. V tom já se pohybuju vlastně pořád nebo od začátku té kariéry učitelské. Takže pro mě je to vlastně přirozený stav. (učitel Jan) 
Z celkového pohledu je možné $v$ postojových trajektoriích této skupiny učitelů vidět dvě tendence. První charakterizují učitelé, kteři v počátku měli vưči reformě vlastní očekávání (pozitivní/negativní), prožili silný moment, který jejich počáteční pocity zeslabil, nebo umocnil, a $v$ konečné fázi se ztotožnili s reformou a přijali ji. Druhá tendence značí stabilnější pozitivní postoj $\mathrm{k}$ reformě, bez vnějších vlivů a prožitých silných momentů, které by měly na postoj k reformě vliv.

\subsection{Neutrální postoje - balancující učitelé}

Postoje učitelů, které v této studii označujeme jako neutrální (celkem u 7 učitelů), značí ambivalenci spočívající v koexistenci pozitivního a negativního vnímání kurikulární reformy, $v$ konfliktu mezi přesvědčeními a pocity, anebo $v$ celkové nevyhraněnosti postojů (srov. Ajzen, 2001; Thompson, Zanna, \& Griffin, 1995). Typické pro tuto skupinu respondentů je také vnímání chybějícího dopadu reformy.

$\checkmark$ prípadě ambivalence jsou si respondenti vědomi pozitivních i negativních stránek proběhlé reformy, nelze však jednoznačně říci, která stránka převažuje. Respondenti často balancují na miskách vah, přičemž reformu na základě zkušeností z praxe $z$ jedné strany přijímají, z druhé strany problematizují.

Toto balancování se projevilo např. v tématu nových vzdělávacích cílů, které kurikulární dokumenty přinesly. Jiřina je reflektuje na pozadí dřivější „zelené knižky“. Na současných dokumentech oceňuje jejich konkrétnost a zároveň vyzdvihuje lepší přehlednost dokumentů předchozích:

Zelená knížka pro mě byla i ze strany pedagoga, nebo ze strany učitele prostě přehlednější, kterou jsem otevřela a věděla jsem, podle čeho... Je fakt, že těch cílů a toho, tam bylo málo, to zas ta změna, tahle, co ted' přišla, je $v$ tomhle pozitivnější, že ty cíle se víc konkretizovaly a specifikovaly, jo, ale za sebe mluvím, tak prostě zelená knížka se mi podle ní učilo líp, nebo učilo, prostě hledalo se mi v ní líp. (učitelka Jiřina)

Předchozí kurikulární programy slouží jako referenční rámec ke zhodnocení současné reformy i u dalších učitelů. Přesvědčení o předchozím stavu chápeme jako přirozenou součást hodnocení změn a jako jednu z možných proměnných, které mohou postoje $k$ reformě ovlivňovat (viz Waugh \& Punch, 1987). Na prípadech Regíny a Venduly je pak možné v porovnání s Jiřinou vidět, že žádnou zásadní změnu ve vztahu k výuce ve srovnání s předchozím kurikulárním dokumentem nevnímají. Např. Vendula uvádí:

... že bych já osobně viděla nějakou změnu oproti tomu, když se učilo podle osnov, to bych zas až tak neviděla. (učitelka Vendula)

Chybějící změnu pak Vendula sama vysvětluje formalismem při zavádění dokumentů, který měl za následek nepřijetí reformy učiteli: 
Myslím, že to zůstalo všechno opravdu v té formální podobě. Že se to prostě neprosadilo tak, aby to bylo do praxe a aby to bylo něco, co by si učitelé vzali za své. (učitelka Vendula)

Trajektorie balancujících jsou oproti fandícím učitelům ještě více rozmanité a individualizované. Např́klad na př́padě Jiřiny můžeme pozorovat tuto trajektorii: negativní očekávání - žádný silný moment - současný neutrální postoj. Jiřina měla na počátku silná negativní očekávání vǔči reformě v době před odchodem na mateřskou dovolenou, kdy sledovala prípravy na zavádění reformy zpovzdálí a vnímala je s obavami z nových povinností. Při utváření jejích očekávání pravděpodobně sehrála významnou roli komunikace s učitelským sborem (zprostředkovaná zkušenost jako determinant budoucích postojů - viz Albarracín, 2002, či sdílená persvaze - viz Kruglanski \& Stroebe, 2005), který ji tyto obavy zprostředkoval:

Samožrejmě, že jsem se bála, protože ... tu změnu jsem zažila opravdu fakt minimálně, ... spíš jsem zažila ten šrumec toho týmu... A ted' prostě viděla jste v očích, ... že ty kolegyně neví, neví prostě, kam šáhnout, co dělat. ... Opravdu ani i ze shora nějaký pokyny přesný nebyly, takže každý se $v$ tom opravdu koupal...

Takže když jsem vlastně odcházela na tu mateřskou, tak jsem si říkala, no až přijdu po těch x letech, tak to bude možná... pro mě hrozný. (učitelka Jiřina)

Současný postoj Jiřiny, který jsme vzhledem k jeho ambivalenci klasifikovali jako neutrální, je možné interpretovat jako reakci na nepř́jemné zkušenosti, které se jí pak podařilo překonat (viz Olson \& Stone, 2005). V současnosti relativizuje dopad reformy např. v souvislosti s časovou zátěží:

Tak já bych řekla, že mě to žádný časový plus ani mínus nepřineslo, že jsem na tom úplně stejně jako před reformou, jo, že mě to časově nezatížilo, abych musela říct, přišla reforma a já se tomu věnuju daleko víc. (učitelka Jiřina)

Jiřina je př́kladem učitelky, u niž je ve výrocích možné zaznamenat rozpor mezi jednotlivými složkami postoje. Učitelka se kognitivně „sžila“ s reformou (přesvědčila sama sebe k akceptaci změn), s kurikulárními dokumenty pracuje, ale neztotožňuje se s reformou emocionálně:

Já si myslím, že jsme se s tím... nebo já sžila, že to prostě př̌̌̌lo a člověk se $v$ tom naučil hledat a vzal to tak, jak to je, a naopak se snažil hledat nějaký cesty, jak to přijmout. (učitelka Jiřina)

Lze dovodit, že u ní dochází ke kognitivní disonanci (viz Festinger, 1957; Olson \& Stone, 2005). Jinými slovy, učitelka jedná jinak, než jak to sama cítí.

Trajektorie společná pro Vendulu a Anežku se vyznačuje pozitivními očekáváními - žádným silným momentem - současným neutrálním postojem. Obě měly pozitivní očekávání, avšak nedošlo $\mathrm{k}$ jejich naplnění, resp. došlo $\mathrm{k}$ velkým rozdílům mezi očekáváním a realitou. Dokumentují to následující výroky. Anežka očekávala od reformy kurikula větší autonomii při výuce, přičemž by navržené kurikulum sloužilo 
82 jako nástroj k evaluaci dosažených výsledků žáků. Vendula doufala v redukci učiva ve svém předmětu:

Myslím, že rozdíly jsou velké, protože když jsme do toho šli, tak jsme měli představu, že v podstatě každý učitel bude ručit jenom za to, že to dítě se za ten rok naučí to, co se naučit má, a každý učitel si to poskládá podle svého, bude si to učit podle svého a jenom prostě třeba o pololetí a na konci roku se nějakým způsobem vyzkouší, jestli ta třída má zvládnuté to penzum, jestli to odpovídá. (učitelka Anežka)

Tak jako my jsme se s některými kolegy opravdu těšili, že tam těch věcí ubude. Že tam bude větší svoboda a ubude třeba i v tom dějepise. Neučím teda dějepis, ale hovořili jsme o tom. A nakonec se tedy nevyškrtalo nic, a pokud já bych mluvila za výchovu ke zdraví a výchovu k občanství, které jsem opravdu zpracovávala, tak tam se stále přidává. Takže to, co mělo být původně, že se nepůjde po tom obsahu, po těch vědomostech, tak mi prijide, že se z ministerstva stále přidává a je to kontraproduktivní k tomu, co měl být cíl. (učitelka Vendula)

Uvedené výroky dokládají výhrady učitelek vůči realizaci reformy na vlastní škole a vypovídají o jistém zklamání z nesplněných příslibů reformy týkajících se učebních obsahů. V současnosti však učitelky chápou reformu jako „nutné zlo“ (Anežka) či nevnímají ve spojitosti s reformou podobně jako další respondenti žádnou změnu:

Je to čistě jenom takový administrativní prvek, který ale v podstatě na realitě v té škole nezměnil nic. (učitelka Vendula)

Zkušenosti učitelů z praxe se ukazují jako zásadní při bilancování př́nosů reformy. Spíše než jeden silný moment do hry vstupuje vícero zážitků a potřeb, které s odstupem času zřejmě odeznívají. Nevyhraněnost postojů může být dána jak časovým, tak emočním odstupem, kdy se počáteční pocity respondentů zmírnily, patrně kvůli chybějícím (žádným) podnětům, které by tyto postoje umocňovaly nebo „oživovaly“ (viz Fabrigar, MacDonald, \& Wegener, 2005). Jak uvedla již zmíněná učitelka Vendula, reforma již není aktuálním tématem:

Nemám ten pocit, že by to byla, nechci říct priorita, ale nemám pocit, že by to bylo něco, co by vůbec, jak kdyby to ani neproběhlo, jak kdyby se nad tím zavřela voda, a ted' už vůbec se o reformě nehovoří. (učitelka Vendula)

I když u balancujících učitelů nacházíme podobnosti s fandícími učiteli v tom, jak se s negativními aspekty reformy s postupem času do jisté míry sžili, můžeme vidět, že silné momenty balancujících se ukazují jako méně dominantní (i v porovnání s rozčarovanými učiteli). Balancující učitelé si většinou nespojovali s reformou žádná očekávání a ani neprožili, resp. netematizovali žádný významný silný moment, který by $v$ jejich postojové trajektorii sehrál důležitou roli.

Výjimkou z hlediska změn v postojových trajektoriích balancujících je Josef: žádná očekávání - negativní silný moment - současný neutrální postoj. Jak sám uvádí, prožil „všechny fáze“ toho, jak „se lidé staví k novým věcem“: 
... odmítnutí, popření, výmluvy... Pak teda nějaké přijetí, které vygradovalo nějakým odevzdáním toho příslušného dokumentu. ... Asi jsem taky sám nebyl úplně teda jako přesvědčený. (učitel Josef)

V jeho postoji tak zřejmě hrála roli podobně jako u Jiřiny sdílená persvaze (viz Kruglanski \& Stroebe, 2005), sdílené negativní vnímaní reformy učitelským sborem, která jeho počáteční negativní postoj k reformě mohla ovlivnit. Dnes reflektuje svou účast při zavádění dokumentů s pozitivním nadhledem:

Ted'ka s odstupem jsem rád, že jsem u toho byl. ... Ale $v$ tom procesu tvoření mi tahle ta role moc jako... neseděla, protože jsem taky byl od začátku mezi těmi skeptiky, tak mi byla spíš teda jako na obtíž. (učitel Josef)

S odstupem času si Josef spojuje s reformou jak její negativní, tak pozitivní aspekty, které učitelům přinesla. Např. v následujícím výroku vnímá formalismus jako jedno z pochybení při zavádění a vedle toho reflektuje autonomii učitele při tvorbě kurikula jako možnost nalezení přijatelné cesty k naplnění požadavků reformy „shora“:

To, co se tady před léty odehrálo, se odehrálo hodně formálně, ... prritom je to třeba chyba, škoda. Myslím si, že když ty školy volají po některých věcech, tak vlastně ve skrytu volají po nějakém nalajnování, velmi často, a neuvědomují si, velmi často, že ho vlastně mají ve své moci a že je to takový hezký kompromis mezi tím nalajnováním a jejich nalajnováním... A jestli $k$ tomuhle dojde, $k$ takovému tomu zpětnému sebeuvědomění si, tak bych byl rád. (učitel Josef)

Shrneme-li hlavní rysy trajektorií balancujících učitelů, všimneme si, že jejich trajektorie kromě Josefa neprošly zásadním zvratem (změnou z hlediska přepólování postoje). Bud' tito učitelé neprožili žádný silný moment, nebo zároveň neměli vưči reformě ani žádná očekávání. Dưvodem chybějící změny v trajektorii může být to, že se učitelů ani jejich očekávání, ani prožité silné momenty nedotkly v osobní rovině natolik, aby to zásadním způsobem ovlivnilo jejich současný postoj (srov. Výrost, 2008). Nabízí se však i otázka, zda právě chybějící podněty nemohly být silným momentem k tomu, že se jejich pozitivní očekávání proměnila v neutrální postoj. Jinými slovy, učitelé mohli chybějící dopad reformy vnímat jako negativní signál (že se nic nezměnilo), který vedl k zaujetí neutrální pozice.

\subsection{Negativní postoje - rozčarovaní učitelé}

Skupina s převažujícími negativními postoji je nejméně zastoupenou skupinou (celkem 4) ${ }^{11}$. Pro tuto skupinu je charakteristická převaha negativ, která si s reformou spojují, a hledání viníka, který je zodpovědný za selhání implementace reformy. Tito

11 Paradoxně vzhledem k předchozím výsledkům dotazníkového šetření, které poukázalo na převažující zastoupení učitelủ se spíše rezistentními postoji ke kurikulární reformě (Pešková, Spurná, \& Knecht, zasláno redakci). 
84 učitelé kritizují její průběh i podmínky, za kterých byla realizována. Např. učitel Svatopluk vidí viníka ve vysokých školách, které měly reformu realizovat a poskytnout tak školám omezenou volnost při tvorbě kurikula:

Vysoké školy, pedagogické ústavy. Tyto instituce měly stanovit zásadní, hlavní kritéria, přes které nepojede vlak. Nás školy pak třeba přinutit, nadstavbu dodatečně udělat na region, vypracovat k tomu DUMy. (učitel Svatopluk)

Výsledné postoje je možné charakterizovat jako celkové neztotožnění se s reformou, které v některých př́ípadech pramení až z negativních pocitů - naštvání a skepse:

Já jsem se s reformou neztotožnil, vnitřně nepřijal. (učitel Svatopluk)

Naše nadšení postupně vyhasíná a ted' jsme naštvaný. (učitelka Klára).

Jak dále dokládáme, pro trajektorie postojů učitelů s převažujícími negativními postoji jsou společná pozitivní nebo žádná (neutrální) očekávání a silný negativní moment, který měl patrně značný vliv na formování výsledných postojů.

Pro učitelku Kláru a učitele Svatopluka je charakteristická tato trajektorie: pozitivní očekávání - negativní silný moment - současný negativní postoj. Oba spojují velká pozitivní očekávání. Učitelka Klára popisuje své pozitivní pocity, které měla v souvislosti s novou rolí spolutvưrce školního vzdělávacího programu a které vedly k vlastní angažovanosti učitelky při přípravě na práci s kurikulárními dokumenty:

Já jsem se na to fakt těšila a moc jsem se o to zajímala, fakt jsem tiskla dokumenty, četla jsem na internetu, fakt jsem se snažila hrozně moc tomu věnovat. ... [My] jsme měli očekávání, že budeme moct, najednou, že budeme tvořit, že si to můžeme užívat i my učitelky. (učitelka Klára)

Vedle toho měla Klára i pozitivní očekávání vưči př́islušným osobám (koordinátorovi), které jí měly poskytnout potřebné pokyny:

Myslím si, že ta reforma vypadala moc hezky... a hrozně jsem se těšila, že mi někdo řekne, udělej to a to. (učitelka Klára)

Učitel Svatopluk měl již konkrétní očekávání vůči reformě, a to v souvislosti s novým vymezením učiva a s novými podmínkami pro učitele. Očekával, že učivo bude na jednu stranu státem předepsané a na druhou stranu si jej bude moci škola do jisté míry uzpưsobit:

Myslel jsem si, že bude učivo pevně v ročnících stanoveno, a já jsem měl představu, že škola si stanoví třeba 10 \% na regionální podmínky v každém předmětu. ... Region si namontuje do ŠVP a povinně bude využívat, co ve svém regionu má. A bude to navazovat tematicky na RVP. (učitel Svatopluk)

Zároveň doufal ve zlepšení materiálních podmínek pro učitele: 
... Při startu RVP, kdy se reforma rozjižděla, slibovaly se i prebendy, spolu s dobrými podmínkami, které kantoři budou mít. Nadstandartní práce nebyly vůbec oceněny a navíc nebyly ani materiální podmínky, peníze na pomůcky, vybavení. (učitel Svatopluk)

Velká očekávání obou učitelů vưči reformě se však vlivem zkušeností střetla se silnými momenty, které učitelé prožili při realizaci reformy v praxi. Učitel Svatopluk tuto změnu popisuje jako velký zlom pro učitele:

Bylo to takové dost zvláštní, dalo by se říci, že reforma byla veliký převrat, veliký skok. $\mathrm{Na}$ kantory zapůsobila jako lavina a ne všichni ji vzali za svou. (učitel Svatopluk)

Jeho očekávání vưči dokumentům a dobrým materiálním podmínkám nebyla naplněna a zkušenosti při zavádění reformy s sebou přinesly problémy, což se projevuje v jeho celkovém negativním hodnocení reformy:

... ale RVP, já se Vám přiznám, že jsem úplně nevzal za své. Já jsem tam viděl věci, které mně vadily. Zejména tzv. svoboda úprav učiva, zařazování učiva do ročníků. Že prostě je možné určitým způsobem si upravovat základní věci do jisté podoby a pak nastane problém při přechodu žáků, při přestěhování a podobně...

Je to katastrofální, reforma nebyla podložena vůbec finančně. Takže finanční oblast se setkala u kantorů s nevděkem. Tohle nás naprosto trápilo, že my se nemưžeme nějak rozjet, to nás limitovalo. (učitel Svatopluk)

U Kláry byl silný moment spojen s pocity bezradnosti a zmatku, které prožívala v průběhu zavádění kurikulárních dokumentů do praxe:

Neskutečný chaos. Pořád jsem $v$ tom hledala systém, že asi to $v$ tom právě nevidím, že jsem prostě někde něco nepochopila. (učitelka Klára)

Tyto pocity pak vysvětluje v souvislosti s chybějícími pokyny a spoluprací ze strany vedení a koordinátora ŠVP:

Naprosto shůry nebyly podávaný systematický, jednoznačný pokyny, abychom budovali nějakou pyramidu. Takže ze začátku, když jsme byli dole $v$ tom, tak jsem chápala, že všichni všechno děláme, takže tomu nemưžeme rozumět, my zespoda, ale že ti nad námi nás povedou... (učitelka Klára).

Chybějící tvưrčí prostředí, chaos a neporozumění utlumily Klářino počáteční nadšení a potřebu změny a práce s kurikulárními dokumenty. Práce s ŠVP zůstala pouze formalizovaná, což dnes přičíá především pochybení ze strany vedení a chybějící spolupráci mezi učiteli na škole:

Po deseti letech mě to hrozně mrzí, že to není živý dokument, se kterým bychom mohli tvořit, ale že to je nařizení shůry, které je negativní pro nás, pro učitelky: musíme to opravit, musíme předělávat, doplňovat. Ale my, když do toho šáhneme, nikdo neví co, do toho šáhla kolegyně, jak, co tam upravila. ... Taková spolupráce, taková kooperace je hrozně... Jakoby těžký to je, těžkopádný, pro mě, pro učitelku. (učitelka Klára) 
Druhá trajektorie rozčarovaných charakteristická pro Patricii a Julii je obdobná jako u Kláry a Svatopluka s rozdílem chybějících očekávání vưči reformě: chybějící očekávání - negativní silný moment - současný negativní postoj. Podobně jako u Kláry negativní silný moment spojený s bezradností zažila i učitelka Patricie, která po obsahové stránce neměla vưči reformě žádná očekávání, ale při nástupu reformy prožívala pocity strachu pramenící z nepřipravenosti na práci s kurikulárními dokumenty:

Já jsem v tom docela plavala..., takže jsem... se toho i trochu bála, jo, že jsem teda nevěděla vůbec, co mě právě čeká, nebyla jsem na to připravená. (učitelka Patricie)

K negativním pocitům $v$ osobní (individuální) rovině přispěla časová náročnost nových povinností, časový tlak a chybějící informace:

Takže to zavádění nebyla pro mě přijemná věc a i z časových důvodů mi to zabralo hodně práce. (učitelka Patricie)

Učitelka dnes stále vnímá problémy a negativa spojená s reformou a i po čase se s reformou neidentifikuje, přestože s dokumenty (z nutnosti) pracuje:

Přizpưsobila jsem se tomu, co nám předali, takže čerpám z toho, pracuji s tím, ale opravdu se vším teda neztotožňuji. (učitelka Patricie)

Učitelka Julie reprezentuje případ učitelky stále rezistentní vưči reformě. Sice také zpětně nereflektuje žádná vlastní očekávání vưči reformě, ale již od doby jejího zavádění s reformou zásadně nesouhlasí a nevnímá v ní v kontextu školy, kde působí, žádná pozitiva:

Osobně říám na rovinu, že jsem měla v té době pocit, že je to věc, která není pro naši školu úplně přínosná. (učitelka Julie)

Přestože v její postojové trajektorii není její silný moment zcela zřejmý (není spojen s konkrétními negativními situacemi a emocemi jako u ostatních rozčarovaných učitelů), je patrné, že se její negativní postoj k reformě vlivem zkušeností nezměnil. Julie kritizuje průběh a podmínky reformy, přičemž silným referenčním rámcem jsou pro ni podobně jako u některých balancujících učitelů předchozí kurikulární dokumenty („osnovy“), které považuje za více vyhovující, např. z hlediska rozvržení učiva:

Vlastně to učivo pro žáky na prvním stupni bylo více rozmělněno, že to nemuseli zvládnout za půl roku, ale měli opravdu na to celý ten první stupeň. A zvláště mám na mysli ted' učivo českého jazyka. (učitelka Julie)

Celkově vzato, pro trajektorie všech rozčarovaných učitelů jsou typické negativní postoje již od doby zavádění. Učitelé prožili negativní silný moment, který 
ovlivnil jejich počáteční pozitivní nebo neutrální postoj k reformě natolik, že se stali vůči reformě resistentní. $V$ př́padě Svatopluka a Kláry lze tuto změnu přičíst silným emočním prožitkům spojeným s negativními zkušenostmi (srov. Vähäsantanen \& Eteläpelt, 2011).

\section{Jak se proměňují postoje učitelů $\mathrm{k}$ reformě - diskuse a závěry}

\subsection{Očekávání vs. silné momenty učitelů}

Cílem této studie bylo popsat proměny postojů učitelů ZŠ ke kurikulární reformě a jejímu zavádění. Na postoje jsme nahlíželi v dynamice jejich proměn, přičemž za podstatné determinanty proměn postojů jsme považovali očekávání vưči reformě a významné zkušenosti (silné momenty), které v souvislosti s reformou učitelé zažili.

Ukazuje se, že sledování obou determinant s časovým odstupem má svưj smysl, jelikož sehrávaly ve vývoji postojů svou roli. Co se týče očekávání vůči reformě, došlo v řadě případů učitelů (fandících a rozčarovaných) ke konfrontaci. Jejich počáteční pozitivní očekávání nebyla vlivem prožitých negativních zkušeností naplněna, což mělo na postoje negativní dopad. Při zavádění reformy se vlivem silných momentů stavěli k reformě negativně. Záleželo pak na dalších kontextových/osobnostních faktorech, které přispěly k prohloubení negace (např. chybějící spolupráce v kolektivu, formalismus) nebo pozvolnému vyprchání či zmírnění negativních emocí (např. časový odstup, získaná jistota při tvorbě a realizaci kurikula). Je třeba však upozornit i na skutečnost, že očekávání souvisejí s obecným postojem ke změně, kterou každý jedinec zvládá různě. Vnímaná naplněnost očekávání tedy mưže být také ovlivněna tímto obecným postojem.

Na silné momenty jsme nahlíželi jako na zkušenosti učitelů z hlediska podmínek a prostředků, které respondenti vnímali v kontextu své vlastní praxe, a jejich výsledky v emocionální rovině (pocity skepse, zklamání, bezradnost, popření, lhostejnost apod.; viz také van Veen \& Sleegers, 2006). Ve výpovědích učitelé zmiňovali převážně negativní emoce, což je pro tak velkou změnu, jako je reforma, typické (Day, 2002). Výzkum přitom ukázal, že pokud se emotivní složka postoje k reformě opravdu silně naruší, může se výsledný postoj i diametrálně změnit (z pozitivního pólu na negativní, jako tomu bylo např. v prrípadě učitelky Kláry, nebo z negativního pólu na pozitivní v případě učitele Jindřicha; srov. van Veen \& Sleegers, 2009). Vysvětlení tohoto zjištění je možné najít i v odborné literatuře. Vzhledem k dominantnímu postavení emocí v postojích (silnému emočnímu prožitku dané zkušenosti či situace) je možné radikální změnu postoje přičíst právě emocím, které mohou ovlivňovat ostatní složky postojů (Ajzen \& Fishbein, 2005).

Jak naznačují naše zjištění, postoje učitelů se v čase vyvíjejí, a to s měnící se intenzitou prožívání (srov. van Veen \& Sleegers, 2009). S časovým odstupem může dojít k odeznění počátečních silných emocí, což dokládají případy učitelů, kteří zaži- 
88 li negativní silné momenty, avšak po čase se „zklidnili“ a naučili se reformu přijímat nebo ji respektovat. Naopak u učitelů se stabilními (obzvláště negativními) postoji se jejich negativní/pozitivní postoj k reformě od prožitého silného momentu nezměnil, což je pravděpodobně dáno vlivem dalších přibývajících negativních/pozitivních zkušeností a prožitků (viz Vähäsantanen \& Eteläpelt, 2011).

Zajímavým zjištěním našeho výzkumu je také skutečnost, že učitelé, kteři žádný silný moment netematizovali (pravděpodobně tedy neprožili), zastávají v současnosti k reformě neutrální nebo převážně pozitivní postoj. Otázkou však zůstává, zda to znamená, že nebyli v průběhu zavádění reformy ovlivněni negativními vnějšími okolnostmi či se jedná o typ lidí se stabilními osobnostními dispozicemi.

\subsection{Současné postoje učitelů a významná témata reformy}

Přestože je $v$ našem výzkumném souboru možné nalézt některé podobnosti v postojových trajektoriích učitelů, nelze vytvořit $z$ tohoto hlediska jednoznačnou typologii učitelů. Výzkum poukázal na značné individuální rozdíly $v$ trajektoriích, které přisuzujeme významu kontextu školy, různorodosti prožitých zkušeností a osobnostním charakteristikám daného učitele (srov. Vähäsantanen \& Eteläpelt, 2011). Jak naznačují i jiné studie, různí učitelé reagují na stejnou reformu odlišně (viz např. van Veen \& Sleegers, 2006). Z těchto důvodů jsme pro prezentaci výsledků volili zjednodušené rozdělení respondentů do tři základních skupin dle převažujícího současného postoje (pozitivní - fandící, neutrální - balancující, negativní - rozčarovaní). Fandící učitele charakterizovala převaha vnímaných pozitiv reformy, ztotožnění se s ideou reformy a odeznění negativních pocitů. Balancující se vyznačovali ambivalentními postoji, přičemž si byli vědomi jak pozitivních, tak i negativních stránek proběhlé reformy. Skupina rozčarovaných pak byla vůči reformě převážně negativně naladěná vlivem různých selhání a nedostatků, které z jejich pohledu reforma přinesla.

Pokud se podíváme na konkrétní témata, která se ve výpovědích učitelů v souvislosti s reformou často objevovala, můžeme si všimnout jistých podobností s jinými výzkumy. Podobně jako např. u Vähäsantanenové a Eteläpeltové (2011), Floresové (2005) a Janíka et al. (2011) náš výzkum naznačil, že existuje ambivalence mezi učiteli, co se týče jejich přesvědčení o různých charakteristikách reformy. Ukazuje se např́klad, že učitelé různě vnímají svoji autonomii při tvorbě kurikula (podobně jako např. ve výzkumu Flores, 2005). Zatímco někteři učitelé ze skupiny fandících vítají svoji autonomii jako možnost uzpůsobení kurikula dle svých potřeb, rozčarovaní si ji spojují s omezením akčního prostoru. Někteří autoři (např. Dahrendorf, 2005; Marková, 2004; cit. dle Moree, 2013, s. 169) spojují rozporuplná očekávání svobody ze strany učitelů $s$ jejich nejistotou $v$ obsazení rolí a platných hodnot. Důsledkem této nejistoty pak mohou být zvýšená očekávání od lídrů či vedení (tamtéž).

Ve výpovědích učitelů také silně rezonovalo téma podmínek a podpory (materiální prostředky, potřeba informovanosti a spolupráce ze strany nadřizených, kolegů atd.) při zavádění kurikula, které bylo učiteli prožíváno s různou intenzitou, resp. s různým efektem na jejich výsledné postoje (viz také Flores, 2005; Lee, 2000; Porubský 
et al., 2016). Např. z hlediska poskytnuté podpory ředitelem při zavádění může při hodnocení reformy učiteli záležet na tom, zda byl ředitel při zavádění dostatečnou podporou učitelům, či se držel spíše v pozadí a implementace probíhala vlastní setrvačností (z hlediska širšího kontextu školy viz dále např. Peterson \& Deal, 2009).

Zajímavým zjištěním v souladu s Floresovou (2005) je také vnímání chybějícího dopadu reformy. Řada učitelů nevnímá v souvislosti s reformou změny na úrovni obsahu kurikula (nevnímá rozdíl ve srovnání s předchozími kurikulárními dokumenty), ale reflektuje pouze změny související s nárůstem pracovních povinností. Vnímání nulového prínosu reformy tak patrně souvisí s tím, že učitelé posuzují dopad reformy v kontextu své výuky, kde nevnímají žádnou změnu (srov. Lee, 2000; Porubský et al., 2016).

\subsection{Závěrem s výhledem}

Naše studie poukázala na důležitost zkoumání procesů změn z perspektivy učitelů, kteři ji prožili a hráli v nich klíčovou roli (viz Hargreaves, 1994). Jako zásadní se jeví poznání významů, které učitelé změně - kurikulární reformě - sami přisuzují (viz také Schmidt \& Datnow, 2005), a jak tuto změnu hodnotí v daném kontextu (prostoru a čase). Na změnu, jako je kurikulární reforma, je proto třeba pohližet jak skrze osobní změny u jednotlivých učitelů, tzn. skrze jejich přesvědčení, pocity a jednání, jež si s těmito procesy změn spojují (viz Goodson, 2001), tak skrze kontext (kulturu) školy, v níž působí. Výpovědi učitelů naznačují, že kontextové faktory materiální (např. dostupnost materiálních prostředků) i nemateriální (vnímaná podpora ze strany vedení a kolegů, spolupráce v učitelském sboru) povahy sehrávají v postojích učitelů důležitou roli a často mají na proměnu postojů vliv. Zejména problematika vztahů je klíčem k pochopení celkové situace na školách (viz např. Hargreaves, 1994) a nabízí další možnost zkoumání k odhalení proměn postojů v kontextu školy. Nabízí se možnost blíže nahlédnout na roli osoby ředitele jako jednoho z ukazatelů vztahů ve škole (viz Peterson \& Deal, 2009).

Kultura školy vždy zásadně ovlivňuje to, jak se učitelé v jejím prostředí cítí a jakých dosahují výsledků (Moree, 2013). V souvislosti s jejím negativním působením lze dokonce hovořit o toxické kultuře (Peterson \& Deal, 2009). Jedná se o souhrn chybějící vize, destruktivních príběhů, které se mezi lidmi vyprávějí, zaměření se na negativní vztahy a pocity neúspěchu (Moree, 2013, s. 27). Taková kultura pak může negativně ovlivňovat jak samotné postoje učitelů k hodnocenému objektu - reformě, tak i jejich výkonnost.

Pro navazující výzkum se jeví jako vhodné nahlížet na postojové trajektorie učitelů $\vee$ širších souvislostech, které by tyto kontextové aspekty zohledňovaly více do hloubky (v rámci dalších analýz dat a dalších výzkumných šetření, např. formou případových studií). V tomto ohledu jsme si vědomi limitu studie, kterým je různá úroveň „sdílnosti“ našich respondentů. Někteří byli v popisu svých zkušeností a postojů méně sdílní, což mělo vliv jak na dokreslení kontextu, tak na samotnou interpretaci postojových trajektorií. 
Jelikož se naše studie zaměřovala na odhalování proměn postojů $\mathrm{k}$ reformě a neměla dostatek prostoru $\mathrm{k}$ detailnímu popisu všech pozitiv a negativ, která si učitelé s reformou spojují ( $k$ tomu více viz např. Janík et al., 2011; Dvořák et al., 2015), nabízí se též možnost se dále věnovat otázce, jaké potřeby, ponaučení a výzvy z pohledu učitelů pro eventuálně budoucí reformu na základě jejich přesvědčení vyplývají. Otázkou však zưstává, do jaké míry je pro učitele proběhlá kurikulární reforma stále živé téma, jelikož dle slov Anny „pořád se děje něco nového a my musíme jít dál“.

\section{Poděkování}

Děkujeme oběma recenzentům za cenné připomínky a náměty, které přispěly ke zkvalitnění tohoto textu.

\section{Literatura}

Albarracin, D. (2002). Cognition in persuasion: An analysis of information processing in response to persuasive communications. Advances in experimental social psychology, 34, 61-130.

Angelides, P. (2001). The development of an efficient technique for collecting and analyzing qualitative data: The analysis of critical incidents. International Journal of Qualitative Studies in Education, 14(3), 429-442.

Ajzen, I. (2001). Nature and operation of attitudes. Annual Review of Psychology, 52(1), 27-58.

Ajzen, I., \& Fishbein, M. (2005). The influence of attitudes on behavior. In D. Albarracín, B. T. Johnson, \& M. P. Zanna (Eds.), The handbook of attitudes (s. 173-222). Mahwah: Lawrence Erlbaum Associates.

Brendl, C. M., Higgins, E. T. (1996). Principles of judging valence: What makes events positive or negative? In M. P. Zanna (Ed.), Advances in experimental social psychology 28 (s. 95-160). San Diego, CA: Academic Press.

Brückmann, M., Duit, R., Tesch, M., Fischer, H., Kauertz, A., Reyer, T., ... Labudde, P. (2007). The potential of video studies in research on teaching and learning science. In R. Pinto \& D. Couso (Eds.), Contributions from science education research (s. 77-89). Berlin: Springer.

Crano, W. D., \& Prislin, R. (2006). Attitudes and persuasion. Annual Review of Psychology, 57, 345-374.

Dahrendorf, R. (2005). Reflections on the revolution in Europe. New Brunswick and London: Transaction publishers.

Day, C. (1999). Developing teacher: The challenges of lifelong learning. London: Falmer Press.

Day, C. (2002). School reform and transitions in teacher professionalism and identity. International Journal of Educational Research, 37(8), 677-692.

Dvořák, D., Starý, K., \& Urbánek, P. (2015). Malá škola po pěti letech: proměny školy v době reformy. Pedagogická orientace, 25(1), 9-31.

Eagly, A. E., \& Chaiken, S. (1993). Attitude research in the 21st century: The current state of knowledge. In D. Albarracín, B. T. Johnson, \& M. P. Zanna (Eds.), The handbook of attitudes (s. 743-768). Mahwah: Lawrence Erlbaum Associates.

Fabrigar, L. R., MacDonald, T. K., \& Wegener, D. T. (2005). The structure of attitudes. In D. Albarracín, B. T. Johnson, \& M. P. Zanna, The handbook of attitudes (s. 79-124). Mahwah: Lawrence Erlbaum Associates.

Fazio, R. H. (1995). Attitudes as object-evaluation associations: Determinants, consequences, and correlates of attitude accessibility. In R. E. Petty \& J. A. Krosnick (Eds.), Attitude 
strength: Antecedents and consequences (s. 247-282). Mahwah: Lawrence Erlbaum Associates.

Fazio, R. H., \& Olson, M. A. (2003). Attitudes: Foundations, functions, and consequences. In M. A. Hogg, \& J. Cooper (Eds.), The Sage handbook of social psychology (s. 139-160). London: Sage.

Festinger, L. (1957). A theory of cognitive dissonance. Stanford: Stanford University Press.

Fishbein, M., \& Ajzen, I. (1975). Belief, attitude, intention, and behaviour: An introduction to theory and research. Reading: Addison-Wesley.

Flores, A. M. (2005). Teachers' view on recent curriculum changes: tension and challenges. The Curriculum Journal, 16(3), 401-413.

Gläser-Zikuda, M. (2008). Qualitative Inhaltsanalyse in der Lernstrategie- und Lernemotionsforschung. In P. Mayring \& M. Gläser-Zikuda (Eds.), Die Praxis der Qualitativen Inhaltsanalyse (s. 63-83). Weinheim: Beltz.

Goodson, I. F. (2001). Social histories of educational change. Journal of Educational Change, 2(1), 45-63.

Goodson, I. F., \& Anstead, C. J. (2012). The life of a school. New York: Peter Lang.

Graham, M., Milanowski, A., \& Miller, J. (2012). Measuring and promoting inter-rater agreement of teacher and principal performance ratings. Center for educator compensation reform. Dostupné z http://files.eric.ed.gov/fulltext/ED532068.pdf

Hardman, J., \& A-Rahman, N. (2014). Teachers and the implementation of a new English curriculum in Malaysia. Language, Culture and Curriculum, 27(3), 260-277.

Hargreaves, A. (1994). Changing teachers, changing times: teachers' work and culture in the postmodern age. New York: Teachers College Press.

Chaiken, S., \& Stangor, C. (1987). Attitudes and attitude change. Annual Review of Psychology, 38(1), 575-630.

Janík, T. (2013). Od reformy kurikula k produktivní kultuře vyučování a učení. Pedagogická orientace, 23(5), 634-663.

Janík, T., Janko, T., Pešková, K., Knecht, P., \& Spurná, M. (2018). Czech teachers' attitudes towards curriculum reform implementation. Human Affairs, 28(1), 54-70.

Janík, T., Knecht, P., Najvar, P., Pavlas, T., Slavík, J., \& Solnička, D. (2010). Kurikulární reforma na gymnáziích $v$ rozhovorech s koordinátory pilotních a partnerských škol. Praha: VúP.

Janík, T., Knecht, P., Najvar, P., Píšová, M., \& Slavík, J. (2011). Kurikulární reforma na gymnáziích: výzkumná zjištění a doporučení. Pedagogická orientace, 21(4), 375-415.

Jorgensen, R., Walsh, L., \& Niesche, R. (2009). Reforming schools: A case study of New Basics in a primary school. International Journal of Leadership in Education, 12(2), 115-133.

Karakhanyan, S., van Veen, K., \& Bergen, Th. C. M. (2011). Teachers' voices in the context of higher education reforms in Armenia. European Journal of Education, 46(4), 508-523.

Krosnick, J. A., \& Petty, R. E. (1995). Attitude strength: An overview. In R.E. Petty \& J. A. Krosnick (Eds.), Antecedents and consequences (s. 1-24). Mahwah: Lawrence Erlbaum Associates.

Kruglanski, A. W., \& Stroebe, W. (2005). The influence of beliefs and goals on attitude: Issues of structure, function, and dynamics. In D. Albarracín, B. T. Johnson, \& M. P. Zanna (Eds.), The handbook of attitudes (s. 323-368). Mahwah: Lawrence Erlbaum Associates.

Lazarová, B. (2005). Osobnost učitele a rezistence vưči změně. Studia paedagogica, 53(10), 109-122.

Lee, J. Ch. (2000). Teacher receptivity to curriculum change in the implementation stage: The case of environmental education in Hong Kong. Journal of Curriculum Studies, 32(1), 95-115.

Marková, I. (Ed.). (2004). Trust and democratic transition in post-communist Europe. Oxford: Oxford University Press.

McHugh, M. L. (2012). Interrater reliability: The kappa statistic. Biochemia Medica, 22(3), 276-282.

Miles, M. B., \& Huberman, A. M. (1994). Qualitative data analysis. An expanded sourcebook. London: Sage. 
92 Moree, D. (2013). Učitelé na vlnách transformace: Kultura školy před rokem 1989 a po něm. Praha: Karolinum.

Moscovici, S., (1984). The phenomenon of social representations. In R. M. Farr \& S. Moscovici (Eds.), Social representations (s. 3-69). Cambridge: Cambridge University Press.

Olson, J. M. , \& Stone, J., (2005). The influence of behavior on Attitudes. In D. Albarracín, B. T. Johnson, \& M. P. Zanna (Eds.), The handbook of attitudes (s. 223-272). Mahwah: Lawrence Erlbaum Associates.

Pešková, K., Spurná, M., \& Knecht, P. (2017). Teoretický model pro výzkum vnímání kurikulárních změn učiteli ZŠ. Orbis scholae, 11(2), 99-124.

Pešková, K., Spurná, M., \& Knecht, P. (zasláno redakci). Teachers’ acceptance of curriculum reform in the Czech Republic: 10 years after. Center for Educational Policy Studies Journal.

Peterson, K. D., \& Deal, T. E. (2009). Shaping school culture: Pitfalls, paradoxes, \& promises. San Francisco: Jossey-Bass.

Petty, R. E., \& Cacioppo, J. T. (1986). Attitudes and persuasion: Classic and contemporary approaches. Dubugue: Brown.

Píšová, M., Kostková, K., Janík, T., Doulík, P., Hajdušková, L., Knecht, P., ..., Vlček, P. (2011). Kurikulární reforma na gymnáziích. Př́ipadové studie tvorby kurikula. Praha: VúP.

Plichtová, J. (1998). Sociálne reprezentácie: Teória, výskum, výzva. Československá psychologie, 6(42), 503-250.

Porubský, Š., Kosová, B., Doušková, A., Trnka, M., Poliach, V., Sabo, R., ... Simanová, L. (2016). Kurikulum základnej školy očami učitel’ov (empirické zistenia). Banská Bystrica: Belianum.

Rekkor, S., Ümarik, M., \& Loogma, K. (2013). Adoption of national curricula by vocational teachers in Estonia. Journal of Vocational Education \& Training, 65(4), 489-506.

Schmidt, M., \& Datnow, A. (2005). Teachers' sense-making about comprehensive school reform: The influence of emotions. Teaching and Teacher Education, 21(8), 949-965.

Spreng, R. A., MacKenzie, S. B., \& Olshavsky, R. W. (1996). A reexamination of the determinants of consumer satisfaction. The Journal of Marketing, 60(3), 15-32.

Spurná, M., \& Knecht, P. (2018). Využívání kurikulárních dokumentů učiteli základních škol: aplikace Johnsonovy typologie. Studia paedagogica, 23(1), 29-54.

Stemler, S. E. (2004). A comparison of consensus, consistency, and measurement approaches to estimating interrater reliability. Practical Assessment, Research Evaluation, 9(4), 1-11.

Straková, J. (2010). Postoje českých učitelů k hlavním prioritám vzdělávací politiky. In R. K. Váňová, Učitel v současné škole (s. 167-175). Praha: FF UK.

Thompson, M., Zanna, M. P., \& Griffin, D. W. (1995). Let's not be indifferent about attitudinal ambivalence. In R. E. Petty \& J. A. Krosnick (Eds.), Attitude strength: Antecedents and consequences (s. 361-386). Mahwah: Lawrence Erlbaum Associates.

Tripp, D. (1994). Teachars' lives, critical incidents, and professional practice. International Journal of Qualitative Studies in Education, 7(1), 65-76.

Tůmová, A. (2012). Effects of age and length of professional experience on teachers' attitudes to curricular reform. Central European Journal of Public Policy, 6(2), 84-99.

Vähäsantanen, K., \& Eteläpelto, A. (2011). Vocational teachers' pathways in the course of a curriculum reform. Journal of Curriculum Studies, 43(3), 291-312.

van Veen, K., \& Sleegers, P. (2006) How does it feel? Teachers' emotions in a context of change. Journal of Curriculum Studies, 38(1), 85-111.

van Veen, K., \& Sleegers, P. (2009). Teachers' emotions in a context of reforms: To a deeper understanding of teachers and reform. In P. Schutz \& M. Zembylas (Eds.), Advances in teacher emotion research: The impact on teachers' lives (s. 233-252). New York: Springer.

Výrost, J. (2008). Postoje, jejich utváření a změna. In J. Výrost \& I. Slaměník (Eds.), Sociální psychologie (s. 127-146). Praha: Grada Publishing.

Watkins, M. W., \& Pacheco, M. (2000). Interobserver agreement in behavioral research: Importance and calculation. Journal of Behavioral Education, 10(4), 205-212.

Waugh, R. F., \& Punch, K. F. (1987). Teacher receptivity to systemwide change in the implementation stage. Review of Educational Research, 57(3), 237-254. 
Mgr. Karolína Pešková, Ph.D., Institut výzkumu školního vzdělávání Pedagogická fakulta, Masarykova univerzita Poříćí 31, 60300 Brno peskova@ped.muni.cz

Mgr. Tomáš Janko, Ph.D., Institut výzkumu školního vzdělávání Pedagogická fakulta, Masarykova univerzita Pořičí 31, 60300 Brno janko@ped.muni.cz

doc. PhDr. Tomáš Janík, Ph.D., M.Ed., Institut výzkumu školního vzdělávání Pedagogická fakulta, Masarykova univerzita Pořičí 31, 60300 Brno tjanik@ped.muni.cz

Mgr. et Mgr. Michaela Spurná, Ústav pedagogických věd Filozofická fakulta, Masarykova univerzita Arna Nováka 1, 60200 Brno spurna@ped.muni.cz 